\title{
Determining the Influence of Participatory Evaluation on Conservation of Mau Forest Programme in Bomet County, Kenya
}

\author{
Julius Kibet Cheruiyot ${ }^{1}$, Lillian Otieno Omutoko ${ }^{1} \&$ Charles Mallans Rambo ${ }^{1}$ \\ ${ }^{1}$ School of Open and Distance Learning, University of Nairobi, Kenya \\ Correspondence: Julius Kibet Cheruiyot, Department of Open Learning, University of Nairobi, Kenya. E-mail: \\ julikibet2@gmail.com
}

Received: August 1, 2020

Accepted: September 21, $2020 \quad$ Online Published: April 15, 2021

doi:10.5539/jsd.v14n3p78

URL: https://doi.org/10.5539/jsd.v14n3p78

\begin{abstract}
Forests are considered the second most important natural resource after water throughout the world. There is need to undertake review of policies and legislation on forestry to incorporate aspects of Participatory Forest Management to conserve and manage resources in a sustainable way. The paper sought to determine the extent to which Participatory evaluation influences conservation of Mau Forest programme. This study was guided by descriptive survey and correlational research designs. A sample size of 364 respondents was drawn from a target population of 4100 people using Yamane (1967) Formula.From the findings, $r=-0.048$ indicated that there was a weak negative linear correlation between Participatory evaluation and Conservation of Mau Forest programme. With a $p$-value $=0.43$ ), the null hypothesis was not rejected and recommended that there is need to do a holistic analysis of local people, their livelihood assets and strategies, resource-use patterns and power relations before the implementation of conservation programs.
\end{abstract}

Keywords: conservation, forests, participatory evaluation, participatory forest management, Mau forest

\section{Introduction}

The world forest area is just over 4 billion hectares, equal to $31 \%$ of the total area and averaging 0.6 ha per capita (FAO, 2010). Forests are considered the second most important natural resource after water throughout the world. Forest industries globally are now supplying jobs to about 60 million people, with around one billion depending on medicinal products from forest plants (World Bank 2006). They act as a source of food, oxygen, housing, leisure and spiritual sustenance and provides raw material to over 5000 commercially traded products varying from clothing to pharmaceuticals and timber products (CBD 2009). Forest has a wide variety of important environmental and ecosystem features, and is the habitat to most animal and plant species worldwide. In terms of the cultural, social and economic value of forests (Abass 2007), humans have traditionally attributed a moral, metaphysical and esthetic importance to the forest.

Rural communities, directly or indirectly, depend on forests for their everyday life and income demand in SubSaharan Africa and parts of Asia such as Nepal and Bangladesh (Kaimowitz, 2003; Phiri, Chirwa, Watt \& Syampungani, 2012). Forest resources act as a security for rural populations between harvesting season and other difficult times such as crop loss, drought and social conflicts (Fisher, 2004). In addition, McDermott and Schreckenberg (2009) proposed that forestry is often the most widely accessible resource in the villages. Furthermore, Agrawal, Cashore, Hardin, Shepherd, Benson and Miller, 2013), argue that historically, Forests is a major factor for industrial growth and production. Forests and land resources, however, are currently diminishing at a fast pace, thereby jeopardizing the potential of existing and future local populations to fulfill their essential needs they have been deriving from forest. Many countries, particularly in Asia and Africa, have since undertaken a forestry review to integrate elements of Participatory Forestry Management in a sustainable manner. Participatory Forest Management (PFM) is commonly practiced as an alternative form of forest resources management in many developed countries (Wily, 2002). The participatory management of forests provides for the conclusion of agreements between key participating parties which identify their positions, responsibilities, advantages and authority in the management of specified forest resources (Matiku, 2011).

Lee and Park (2001) claim that local people's engagement in forest resource management can preserve local ecological legitimacy based on their Asian forestry management research, that forest co - management can promote forestry and forest growth, contribute to poverty reduction and further address their survival needs. In 
addition, various writers, such as Anonymous (2010), Kathleen Wolf, Linda Kruger (2010), and Reddy (2002), have studied Participatory Forests in Europe and the USA. The participatory methodology is considered to be an effective mechanism for forest security, collaboration of forestry and related agencies' relationships and the execution of conflict management. The program was introduced in Bangladesh in the 1980s with the goal of engaging local people in forest resource management.

Participatory forest management is recommended in Ethiopia for NGOs to overcome the issue of forestry degradation (Mustalahti, 2006). The impetus for the PFM program in the Bale region was the protection of the Greater Bale Mountains Eco system's special biodiversity and ecological functions while building and reinforcing sustainable community livelihoods (FARM, 2007). In the last 15 years, PFM has been implemented by the Tanzania government as a key policy for the conservation of natural forests, which are both integrated forest conservation and community-based forest management. Such maintenance technique is currently operating or under implementation process in 3.6 million hectares of forest land and 1,800 villages. Forest management evidence from three case studies, using participatory and non-participatory approaches to forest management indicate that community participation in forest conservation was linked to increasing forest status (Blomley, Fliegner, Isango, Zahabu, Ahrends and Burgess, 2008). It has been three decades since Participatory Forest Management (PFM) was initiated with the ultimate goal of managing land loss, ensuring biodiversity conservation on the one hand and encouraging people to engage and enhance their living standards on the other (Fisher, Prabhu \& McDougall, 2007). The first PFM site in Kenya was at Arabuko-Sokoke Forest established in 1997 but without a supportive legislative framework (Thenya et al., 2007). Today there are over 100 CFAs spread across different parts of Kenya (Ongugo, Mogoi, Obonyo \& Oeba, 2008).

\subsection{Statement of the Problem}

Kenya has a comparatively limited woodlands of about 1.24 million hectares with a closed Canopy Forest, while 0.16 million hectares are cultivated. The total area of forest is under $3 \%$ of Kenya's total area. The forest 's position as a source and sink of carbon dioxide, the big greenhouse gas (GHG), which supports the global warming and climate change is also beneficial to its climate control (Hesslerová and Pokorný, 2010). Most natural forests exist in areas of high opportunity where the stresses and competition are extreme from other modes of land use. It is evident that in 2007, Mau Forest generated revenues of over USD 10 million from Park entrance fees in the Nakuru Park and Maasai Mara Reserve alone (UNEP, 2008). The rivers with their source in Mau generate hydroelectric power with an approximate hydroelectric power output of 535 megawatts representing 57 percent of the overall power generation capacity of Kenya in the year 2009 (GOK, 2009). The net depletion of forests and extensive human invasions between 1989 and 2009 contributed to about $25 \%$ of being more than 107,000 ha of the Mau (GOK, 2009). Land use has significantly changed in the Mau Forest Complex (MFC) due to the rise in human population who demand land to undertake subsistence farming and for settlement. Invasion has contributed to dramatic and significant degradation of land, erosion and loss of once productive upstream wetlands in headwater catchments. Unfortunately, as forest regulations have not yet been established for the Kenya Forest Service and forest management forces are not yet enforced (Matiku et al., 2011). The loss of vegetation cover is attributed largely to the human invasion, the encroachment of forested areas by human settlements, forest fires, illicit logging, cultivation and the excisions of the state (NEMA 2009). Participatory Forest Management is increasingly being used as an approach through which to achieve sustainability of threatened forests and conservation of biodiversity. This is done through a process of inclusion, equity, and democratization of governance of the forest resources (Amanor, 2003). Unfortunately the Forest Act has remained largely unimplemented as the institutional structures for the Kenya Forest Service has not been completed and devolution of forest management powers is not yet to take place (Matiku et al. 2011). Since Forest conservation has not been successful, a study needs to be carried out to determine the influence of Participatory Evaluation on Conservation of Mau Forest Programme in Bomet County, Kenya.

\section{Literature Review}

\subsection{The Concept of Participatory Forest Management}

Anders (2000) noted, the foundation of Participatory Forest Management (PFM) is that local community can and will conserve forests if rendered legal right to access and use the resource to generate tangible benefits - a benefit that confers the retaining of the forests rather than removing them. Indeed, PFM is dualistic in purpose - it is about the economic and social benefits of forest dependent community from the forests, as it is about the conservation of the forest resources. In so doing, PFM establishes an interface where conservation concerns of the State and the livelihood needs of local communities can be served equitably. PFM is not only about benefit sharing, but also about empowerment and decision making on issues that immediately and vitally concern communities. PFM deals 
with community participation as they are gaining a new role as forest managers and legal users, and need to be organized, establish appropriate institutions, define their needs, develop plans and implement the plans to achieve a successful forest management and meet their needs.

The Kenyan government has adopted the PFM framework in appreciation of the part played by local forest societies in reducing the destruction of forest and degradation (MENR, 2005, 2016). First of all, the Forest Act (2005) was already passed and then followed by the National Forest Act (2016). Under the PFM agreement in Kenya, the Government holds possession of the forest and users' rights are acquired by adjacent forest societies, grouped in the form of Community Forest Associations (CFAs). Mbuvi, Maua, Ongugo, Koech, Othim and Musyoki, (2009) posit that in the developing PFM, the state and local communities are engaged in the creation of guidance and agreements on forestry management through the Kenya Forestry Service.

\subsection{Participatory Evaluation and Conservation of Mau Forest Programme}

Environmental conservation programs are both useful and elusive (Conrad, Cassar, Christie \& Fazey, 2011), and no specific metrics are available to quantify them. There are also very few systematic assessment empirical cases (Rowe \& Frewer, 2000). Whilst the scholars accept that the participants in the participatory model may achieve an ideal assessment (Blackstock, Kelly \& Horsey, 2007; Reed, 2008), this is not always the case. Furthermore, those planning a participatory process to implement a Community Based Natural Resource Management (CBNRM) project, it is more important to know what makes a method efficient from the beginning and how findings can be tested. This is in contrast to participants' ex-post appraisal. The appraisal of participatory methods is also assessed by method or result variables, or by both.

In one hand, performance-based evaluations seek to classify the outcomes of a project's success. This could allow results-based assessments to begin by identifying success in the project context, creating and ultimately reviewing metrics and procedures for assessing performance. In the assessment of attendance, the parameters may be helpful but also arbitrary and vary according to the views of the participants. Furthermore, certain causes that have contributed to success may be viewed as contingent on the method and therefore as process-based drivers. Whilst empowerment, for example, is a desirable outcome, it would certainly also be part of a substantial process of engagement. Empowerment infers the re-equalization of power by raising awareness or educating disenfranchised key stakeholders (Potter et al., 1999), although it can and should be seen from multiple contexts (Twyman, Dougill, Sporton \& Thomas, 2001).

On the other hand, the process-based participation assessment relies on the Group involvement requirements that are expected to meet results-based performance metrics. Kapoor (2001) maintains that while group participation systems involved in CBNRM are more suitable and inclusive in terms of meaning than typical top-down systems, their success and importance are determined by a number of factors. They include relationships of influence, inclusiveness and group concepts. A process-based emphasis connected to the result-based performance metrics requires awareness of the diverse views of stakeholders and their engagement to achieve results. A research by Webler and Tuler (2007) found that while most participants accepted that best practices require inclusiveness and transparency, the views on knowledge, leadership and power were strikingly different. This stresses the need to take into account the diversity of members and to assess through group participation mechanisms provided for the inclusion of multiple viewpoints.

The evaluation is in this sense an assessment of tasks that are or have already been done, to see if they help in decision-making and to see if the priorities are achieved. Many programs, including projects, may be evaluated (UNDP, 2009). Assessment is feasible. That is at the center or the end of an effort, and by its very existence it is intermittent. The evaluation process brings the bigger picture and expectations, which are separate from the outcomes, into account and investigates how successful the targets have been achieved. An impact assessment, for example, should be carried out during a project and over a time to determine long-term results. It is systemic, but not constant in nature like monitoring, which focuses on analysing the performance and the changes that resulted in the project. Effect evaluation can include positive or negative information, expected or unintentional, long-term and short-term information about progress. It helps to explain the reasons for the change at the stage of production or end results.

In order to recognize management capabilities, deficiencies and requirements, management assessment is also a method that analyses the inputs, behaviors and outputs of the management operation (NOAA, 2011).They are not correlated with clear success expectations or concrete program rationale, but are based on the premise that conservation interventions with adequate management skill and sufficient practices are more likely to produce beneficial effects rather than low-capacity strategies and bad practices (Ervin, 2003; Leverington et al., 2010).

Management assessments also permits one to know if an action is correctly implemented. Management assessment 
is separate from the assessment of management performance and its relevant instruments, but the data produced from this measurement are commonly used to evaluate the adequacy of management inputs, activities and outputs. The complexities differ but the methods used most frequently are relatively short, easy and cost-effective (NOAA, 2010, 2011). They are used to quantify interference inputs such as finances, workers, operations such as compliance, boundary demarcation and output such as management plans and rules (Ervin, 2003; NOAA, 2011). They also include an autonomous questionnaire. Management assessment has been adopted by over 6200 protected areas globally (Leverington et al., 2010). Management assessments most frequently are used to assess national and regional management and conservation policies. (Pavese, Leverington \& Hockings, 2007; Quan, Ouyang, Xu \& Miao, 2011).

Performance metrics are also used to assess improvement in the direction of stated mission or program goals or policy objectives (DAC, 2002). Performance assessment has been more relevant in the 1980s and early 1990s, as policymakers and players from the private sector have been able to respond to a perceived need for greater transparency about the results of public and private investments in education, public health, social care, and others sectors (Rich, 1998; Wholey, 1997). As a relative latecomer in efficiency assessments, the conservation sector made substantial efforts only after the 1990s (Stem et al., 2005). Numerous methodologies for performance evaluation were then developed by government departments, NGOs and academics (Kapos et al., 2008; UNDP / GEF, 2005). While the term "performance assessment" has often been used interchangeably with efficiency, outcome or result-based administration, performance measurement is understood as an information processing tool, for instance as a decision-making mechanism.

The impact assessment is often a structured method in which the causal consequences of an initiative, program or regulation are measured (Gertler et al. 2011)). In comparing what really happens during an intervention, the impact analysis tests the expected and unintended impacts of environmental action (Gertler, Martinez, Premand, Rawlings \& Vermeersh, 2011). In addition to presenting evidence of positive and negative results, well-designed impact analyses may offer insights into the different results between and within communities, the characteristics and circumstances in which the intervention is likely to succeed or fail (Miteva, Pattanayak and Ferraro, 2012).

Furthermore, the effects on the wildfires, recovery plans on endangered species' status and environmental protection on human health have been investigated by recent impact analyses (Glew 2012). Impact analyses shape decisions about environmental programs to curb, improve and extend conservation measures (Gertler et al., 2011). Accordingly, the application of impact assessments is ideally matched for actively developed interventions or acts, specifying project targets and practices, recognizing possible assessment participants and enticing opportunities for use (GAO, 2009). When the principle of transition that connects policy with effect remains unproven for new or disputed initiatives, impact evaluations may have a relatively strong political significance and ability for policy makers to use (Gertler et al., 2011; Patton, 2003).

In addition, the institutional analysis leads to a common background of facts for policy makers raising concerns as to whether or not an initiative succeeds and its level of impact (Pullin and Knight, 2009). A systematic analysis unit, which puts together matter subject experts and analysis and interpretation experts, is usually performed separately (CEE 2010). Furthermore, comprehensive assessments need extensive technological knowledge, money and time (CEE 2010). While structural assessments are popular in other fields, despite their ability they were not commonly used for conservation. Processes are also needed to incorporate systematic reviews evidence into useful guidance on policies. In order to satisfy the needs of facts and to guide policy making, government departments and NGOs are starting to conduct a systemic analysis (Bowler, Buyung-Ali, Healey, Jones, Knight \& Pullin, 2012). Increased research assessing the effects of environmental behavior would result in a resulting improvement in possibilities for systemic assessment and adaptation of conservation policy.

\subsection{Theoretical Framework}

This study was guided by Forest Transition Theory which applied two main nonexclusive pathways to explain forest transitions (Angelsen and Rudel, 2013). First, the economic development path, which follows the environmental Kuznets curve model, argues that countries are undergoing an initial phase of economic and demographic change and deforestation growth. At a later point in history, economic practices shift from industrial exploitation of resources to an economy focused on the service sector, tourism, higher wages, greater knowledge about the environment, and rural migration into urban areas, decreasing forest demand, and eventually contributing to a regeneration of forests.

The second path described by the Forest Transition Theory is the so called 'forest scarcity path'. Here, deforestation allows the forests' capacity to provide natural resources and products to decline perceptibly. Rising timber prices and growing demand for environmental services from society and the private sector provides incentives for tree- 
planting strategies and practices, general reforestation and woodland restoration, sustainable forest management and the protection of forest reservoirs (Rudel, et al., 2005; Angelsen \& Rudel, 2013). After a period of high deforestation rates, when the forest area has been reduced significantly, a lack of forest resources leads to a reduction in the supply of services offered to populations by forest habitats. This urges governments and land managers to effectively develop afforestation programs. Under this perspective, proposed by Rudel et al. (2005), the forest transition can be explained due to a response by governments and private sector to a perceived scarcity of forests and their direct and indirect goods and services. The forest scarcity can also be perceived due to increases in perceived risks of landslides on deforested slopes, and floods in downstream watersheds. With rising timber and other forest products' prices and a perception of risks related to natural disasters, investments are made by governments and landowners in tree planting and more intensive forest management.

In addition, Angelsen and Rudel (2013) segregate the forest scarcity pathway into two distinct drivers of forest transition that initiate and are addressed through different processes, the inadequacy of forest products and services. The former explains how the inadequacy of forest products due to dwindling size of the forest and rising demand for forest products due to economic growth stimulates forest conservation, sustainable and better forest management, and the establishment of plantations in order to relieve pressure on natural forests, as was observed in India (Kohlin and Parks 2001). Similarly, Foster and Rosenzweig (2003) demonstrate how this higher demand and lower supply leads to higher prices and therefore incentivizes reforestation due to market pressures. The direct involvement of governments in creating policies to incentivize reforestation has also been observed in Niger during the 1990s leading to important increases in forest area (FAO 2010).

The study was guided by a conceptual framework showing the influence of participatory evaluation (independent variable) on conservation of Mau Forest programme (dependent variable). The indicators of participatory evaluation included the extent of forest for scenic and amenity purpose, number of improved stoves, sharing of evaluation results and rate of improved livelihood among the Community Forest Association (CFA) members. Forest conservation programmes are measured through the number of trees planted, fencing off of forest areas, incidences of fires, access to fodder; frequency of wildlife appearance and availability of water sources in the forest area.

\section{Research Methodology}

\subsection{Research Paradigm}

Pragmatism was the driving principle of this paper. For mixed methods, Johnson and Anthony (2004) prove that the pragmatism model is ideally adapted as a testing methodology in mixed methods. The quantitative and qualitative dimensions of PFM, which required pragmatism, were analyzed in this paper.

\subsection{Research Design}

This study used descriptive and correlation model designs because descriptive and inferential data analysis was needed. In this research. The causal effects of relationships as well as the extent to which the combination of the predictor variables influenced the result of the dependent variable, was desired.

\subsection{Target Population}

The study was conducted in the Mau forest conservancy in Bomet County, Kenya. The choice of the Mau forest was based on two criteria: high susceptibility to degradation and a long history of community forestry, with the highest number of CFAs of any forest in Kenya. The paper targeted 4,100 participants comprising of 50 Kenya forest service officers (KFS), 100 chairpersons of community Forest Associations(CFAs) of the and 3,950 households residing adjacent to Bomet County's South-West Mau forest. The four administrative units of the Bomet Forest stations (Itare, Mara-Mara and Ndoinet) have been surrounded by these households (Kenya forest service) (KNBS, 2013). These are the community forest users residing at least five kilometres from the edges of the forest. One person who is household head, alternative head or an adult who was not less than six months in the household was selected for each household. 
Table 1. Target population

\begin{tabular}{lc}
\hline Categories & Number of Members \\
\hline Kenya Forest service officers (KFS) & 50 \\
Forest executive committees of CFAs & 100 \\
Households & 3950 \\
\hline Total & $\mathbf{4 1 0 0}$ \\
\hline
\end{tabular}

\subsection{Sample Size}

Sample size needs to be sufficiently high to represent the universe population according to Kothari (2004). Yamane was used to estimate the sample size (n) based on population size $(\mathrm{N})$, and an error margin (e). The formula was used to determine sample size (n). A random technique of sampling was employed to determine the sample size. The method was chosen because it took the population size into consideration. The paper adopted a confidence interval of 95 percent, resulting to 0.05 level of significance.

$$
n=\frac{N}{1+N E^{2}}
$$

where:

$$
\begin{aligned}
& \mathrm{n}=\text { no. of samples } \\
& \mathrm{N}=\text { total population } \\
& \mathrm{e}=\text { error margin } / \text { margin of error }(0.05) \\
& \mathrm{n}=\frac{4100}{1+4100 x\left(0.05^{2}\right)} \\
& \mathrm{n}=364
\end{aligned}
$$

A sample size of 364 respondents were obtained from a target population of 4100 individuals using the formula above.

\subsection{Sampling Procedures}

This paper employed a multi-stage sampling method owing to the large population of the research scope. Multi stage sampling assisted the researcher to pick respondents across three sampling stages, offering more accurate and equal opportunities for respondents to be chosen from the first process with selected sub-locations and the second stage of home selection and, ultimately, household selection. Oso and Onen (2009) noted that the Multistage sampling method increasingly chooses smaller areas before a random process selects individual members of the sample. Further, Sekaran (2003) points out that a minimum of 30 percent of subpopulations for statistical analysis are required for sampling procedures. 50 per cent of eight sub-locations in Bomet County were picked at the first level around Mau Forest. The 8 sub-locations were distributed alphabetically and each even number was chosen for studies with the range of $50 \%$. The four sub-locations chosen represented the sub-populations of study.

In the second step of the sampling process for testing 4 sub-locations (sub-populations), the households- sample groups were randomly chosen. The households were selected in the field using a random process. Kenya Forest Stations were the crucial factor throughout the use of this technique. In each fourth household; east, west, and third to the north and south, in each homestead, one head of the household was selected randomly, until 351 households were achieved.

In addition, purposive sampling method was employed to pick a respondent from each household who was the head of the household or was an adult household member and had lived in the household for over 6 months because they would have interacted with others on implementation of forest conservation programmes. First, the people were listed so as to compute the probability of selection for each individual using the Le-Brick-Diop-Alemadi technique - recommended for areas with larger households (Le, Brick, Diop, and Alemadi, 2013). The number of households in the selected sub-locations were obtained using the formula below and each sub-location was assigned a proportionate number of sample households.

$$
\text { Sample household at sub - location } \frac{\text { Population households at sub - location x } 351}{\text { Total population of households in sampled study area }}
$$


Additionally, purposive sampling technique was employed to select the respondents from the Community Forest Association (CFA) executive committees and the Kenya Forest Service officers. Therefore, 9 executive Committees of the Community Forest Associations and 4 Kenya Forest Service officers were selected, who were mostly in charge of forest conservation programme were purposefully picked since they were few.

Table 2. Selected sample size

\begin{tabular}{lcc}
\hline Population strata & Target population & Sample size \\
\hline Kenya Forest Service officers & 50 & 4 \\
Forest Executive committees & 100 & 9 \\
Households & 3950 & 351 \\
\hline Total & & $\mathbf{3 6 4}$ \\
\hline
\end{tabular}

\subsection{Research Instruments}

The quantitative data were obtained using a self-administered structured questionnaire. Questionnaires were issued to both the executive committees (CFA) and the household members (CFUGs). Questionnaires were suitable for the analysis, since information gathered could not be directly observed when they asked about individual thoughts, motives, behaviors, successes or perceptions (Mellenbergh, 2008). The use of this method presupposes that subjects understand and elements used in the instrument (Donald \& Delno, 2006). These were in the form of Likert scales, which were embedded in an estimation of five points varying from strongly disagree to strongly agree. An interview guide was also employed to gathering qualitative data. The interview guide was distributed to the Kenya Forest Service officers in Mau Forest.

\subsection{Pilot Testing Research Instrument}

A pilot test on research instruments was conducted in Chepalungu Forest, Bomet County. The pilot test was carried out in accordance with Cooper and Schilder (2007), who recommended that the pilot test should comprise 10 percent of the sample. Thus, the questionnaires were completed by 35 households and 1 community Forest Association. Additionally, the interview guide was responded by $1 \mathrm{KFS}$ officer who was chosen purposely.

\subsection{Validity of the Research Instruments}

Three forms of validity are of concern to researchers: criteria, content and construct validity (Donald \& Delno, 2006). There are three common facets of validity. Huber (2004) describes construct validity as the nature of the psychological construct or characteristic being measured. A measure then is said to possess construct validity to the degree that it conforms to predicted correlations with other theoretical propositions; content related validity as the format and content of the instrument; criterion related validity as the relationship between scores obtained by use of an instrument and scores obtained using one or more instruments or measures.

Content validity was tested to assess the accuracy with which the instruments captured the variables under study. This test of validity method was chosen as it conforms to the study aims and testing methodology. Therefore, expert judgment was sought so as to check for the validity of the research instruments. This was done by the help of research experts from the University of Nairobi, Community Forest Association committees and Kenya Forest Service officers.

In addition, it is shown that the requirement is true if the calculation characteristics are related to its output on another variable (DeVon et al., 2007). This criteria should be relevant; it is deemed to be the right measure; free from bias to give any subject a fair chance to produce reliable outcomes and consistent or reproducible traits (Kothari, 2009). Therefore, the reliability test was done in order to validate this.

\subsection{Reliability of Research Instruments}

This study used a split half technique as a measure of reliability. The method was preferred since only one test administration was required (Allen and Yen, 2002). The best reliability when using split half method is achieved when the two halves are as near parallel as possible (Allen and Yen, 2002) since such halves produces almost equal means, variance and covariances (Chakrabartty, 2011).

To improve reliability, a pilot testing of research instruments was done in Chepalungu Forest in Bomet County. External functionality was approached by clear and intelligible questions, reducing misunderstandings and straightforward answers to the questions. The Alpha Coefficient (Cronbach alpha, 1951) has been used for internal 
reliability analysis. In the pilot test done, the Cronbach Alpha Reliability Coefficient of the investigation method was 0.7186. Since Cohen and Swerdlik (2010) and Nunnally et al. (1978) recommend a minimum acceptable reliability coefficient of 0.70 , then this criterion was fulfilled by the research instrument used in this paper and deemed extremely accurate and ideal for data collection.

\subsection{Data Analysis Techniques}

In this study, mixed method data analysis technique was used for both descriptive and inferential data analysis. Data collected was coded and entered into Statistical Package for Social Sciences (SPSS version 25.0) and evaluated with descriptive and inferential statistics.

\subsection{Quantitative Data Analysis}

The use of absolute and relative frequencies (percentages), central trend measurements and dispersion (mean and standard deviations), was detailed analysis of the non-parametric results. Quantitative data were presented in form of tables and immediately interpreted. Consequently, data was then measured whether it had a strong or a weak central tendency depending on the standard deviation from the arithmetic mean. In addition to reflecting a population heterogeneity, standard deviation measures also confidence for statistical conclusions (Ghahramani, 2000).

\subsection{Qualitative Data Analysis}

Furthermore, qualitative data covered comprised of "discourse and content analysis" which drew upon the analysis of conversations and written text in the context of the views expressed. Qualitative data was analysed on the basis of the content matters. Responses bearing same themes or trends have been classified into clearly defined groups.

\subsection{Inferential Analysis}

The Pearson product moment coefficient of correlation (r) and stepwise regression (R2) analysis were used for the parametric data. The Pearson Product Moment Correlation (r) is a statistical indicator of linear dependence (correlation) between the two variables that may assign their relationship a positive or negative value (Huber 2004). In this analysis Pearson's Product Moment Correlation Coefficient (r) was used to analyze the linear relationship between the main predictor variable and the dependent variable. Hence, inferential data analysis was done using Pearson correlation coefficient, regression analysis (enter method) and multiple regression analysis (stepwise method). Therefore, for the purposes of using parametric statistics such as regression analysis and Pearson correlation, normal distribution of variables were measured. However the regression analysis equation were given for standardized and unstandardized coefficients.

Larry (2013) points out that stepwise step regression (R2) requires statistical models by intentionally choosing the predictor variables without it being backed by the theory. Furthermore, $p$ - value method was used to evaluate the theory as it assisted in agreeing on a null hypothesis and provided a greater insight into the impact of the decision. The significance level of 0.05 was used since it is the level mostly used in project management and it is a universally accepted value for statistical significance. The p-value obtained was interpreted based on the significance level or the alpha level. Due to Singpurwalla (2013), correlation technique is utilized to analyze the degree of relationship between two variables. Therefore, Pearson's Product-moment correlation coefficient was employed to establish the strength and the direction of the relationship between the dependent variable and the independent variable. The simplest form of regression analysis is a univariate model with one independent variable (Singpurwalla, 2013). Univariate regression analysis was utilized to determine the influence of the independent variable on the dependent variable.

\section{Discussion of Findings}

The respondents were requested to give the opinions on their levels of agreement or disagreement based on the statement in a likert scale of 1-5 where: $1=$ strongly disagree, $2=$ disagree, $3=$ Neutral, $4=$ Agree and $5=$ strongly agree. The results are presented on table 3 . 
Table 3. Participatory evaluation and conservation of Mau forest programme

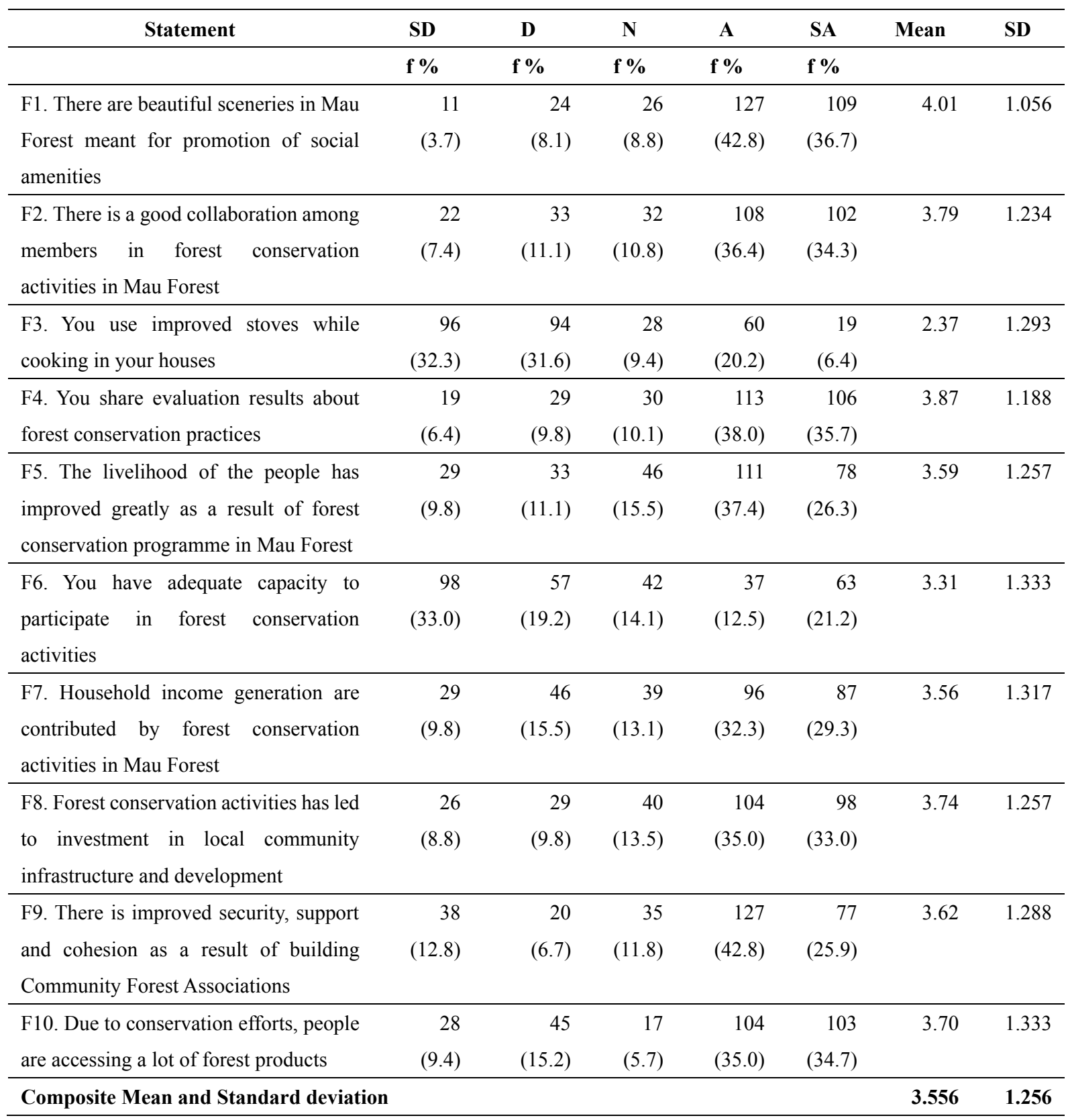

Table 3 showed that on Statement F1- There are beautiful sceneries in Mau forest meant for promotion of social amenities. Out of 297 respondents who participated in the study, 109(36.7\%) strongly agreed that there are beautiful sceneries in Mau forest meant for promotion of social amenities. 127(42.8\%) agreed, 26(8.8\%) were neutral, $24(8.1 \%)$ of the respondents disagreed and 11(3.7\%) strongly disagreed. The line item mean score of 4.01 and SD of 1.056 was greater than the composite mean score of 3.556 and SD of 1.256, implying that presence of beautiful sceneries like huge trees and waterfalls acted as good tourist attraction sites in Mau forest which supported conservation of Mau forest programme. This was supported by qualitative data from KFS officer interviewed who said that:

"There are beautiful sceneries in Mau forest which need to be harnessed for ecotourism. These include presence of giant trees, waterfalls along River Mara Mara, good swamps, fishing camps and rock outcrops." KFS officer

Statement F2-There is a good collaboration among members in forest conservation activities in Mau forest. $108(36.4 \%)$ of the respondents agreed that there is a good collaboration, 102(34.3\%) strongly agreed, 32(10.8\%) 
were neutral, 33(11.1\%) of the respondents disagreed and 22(7.4\%) strongly disagreed. The line item mean score of 3.79 and SD of 1.234 was higher than the composite mean score of 3.556 and SD of 1.256 indicating that existence of good collaboration among the members led to reduction of conflicts as CFA members worked cohesively which promote effective conservation of Mau forest programme.

Statement F3-You use improved stoves while cooking in your houses. 96(32.3\%) of the respondents strongly disagreed that they used improved stoves in their houses. 94(31.6\%) disagreed, 60(20.2\%) agreed and 19(6.4\%) strongly agreed but $28(9.4 \%)$ were neutral. The line item mean score of 2.37 and SD of 1.293 was less than the composite mean score of 3.556 and SD of 1.256. This means that failure by CFA members to use improve stoves in their homes encouraged encroachment of the community to the forest area to extract firewood thus destroying the trees which hinder effective conservation of Mau forest programme.

On statement F4-You share evaluation results about forest conservation practices. 113(38.0\%) of respondents agreed that they share evaluation results. 106(35.7\%) strongly agreed, 30(10.1\%) were neutral, 29(9.8\%) disagreed and $19(6.4 \%)$ of them strongly disagreed. Since the line item mean score of 3.87 and SD of 1.188 was higher than the composite mean score of 3.556 and SD of 1.256 implies that sharing of evaluation results about forest conservation practices enabled members to learn from past experiences and improve in future undertakings while implementing conservation of Mau forest programmes.

On statement F5-The livelihood of the people has improved greatly as a result of forest conservation programme in Mau forest. 111(37.4\%) of the respondents agreed that the livelihood of the people has improved. 78(26.3\%) strongly agreed, 46(15.5\%) were neutral, 33(11.1\%) disagreed and 29(9.8\%) strongly disagreed. The line item mean score of 3.59 and SD of 1.257 was greater than the composite mean score of 3.556 and SD of 1.256 which implies that the wellbeing of CFA members has improved due to their participation in forest conservation activities. The funds obtained from the sale of None Timber Forest Products (NTFPs) and establishment of community based organizations are channeled to improve their standards of living at home. This motivated them to participate further in forest conservation programmes. These findings are in line with those of Lescuyer (2010) who in his study in some villages of South Cameroon revealed that the income from the collection of NTFPs contribute slightly to the overall income of the household. This low contribution of NTFPs to income can be explained by the fact that the populations of these localities consume NTFPs more than they market them. This is in line with the findings of other scholars that, individuals who depend on forest for their income source and livelihood often have positive perceptions of forest management approaches that allow resource harvesting and utilization (Lise, 2000; McFarlane and Boxall, 2000).

Statement F6-You have adequate capacity to participate in forest conservation activities. $98(33.0 \%)$ of the respondents strongly disagreed that they have adequate capacity to participate in forest conservation activities. $57(19.2 \%)$ disagreed, 63(21.2\%) strongly agreed, 37(12.5\%) agreed and 42(14.1\%) of the respondents were neutral. The line item mean score of 3.31 and SD of 1.333 was less than the composite mean score of 3.556 and SD of 1.256. This implies that CFA members face a lot of challenges during implementation of forest conservation activities as they need capacity building to offer skills to CFA members on project implementation through provision of financial incentives and training.

On statement F7- Household income generation are contributed by forest conservation activities in Mau forest. 96(32.3\%) of the respondents agreed that household income generation are contributed by forest conservation activities in Mau forest. 87(29.3\%) strongly agreed, 39(13.1\%) of the respondents were neutral while 46(15.5\%) disagreed and $29(9.8 \%)$ of them strongly disagreed. The line item mean score of 3.56 and SD of 1.317 was greater than the composite mean of 3.556 and SD 1.256.The implication is that alot of products were obtained by the community from the forest including NTFPs such as honey, fodder and herbs which they could sell for income and this positively motivate them to conserve the forest. This confirms a study by Matta and Alavalapati (2005), based on an empirical analysis of joint forest management in India, and explores variations in the perceptions of collective action by community members and factors which affect community perception. A meta-analysis of 51 case studies from 17 developing nations, undertaken by Vedeld et al. (2007), showed that the income from forest products especially wild food, fuel wood and fodder represented a mean of $22 \%$ of the total income in the sampled population. Similarly, Babulo et al. (2009), after sampling 360 rural households in 12 villages in northern Ethiopia, establish that income from forest products occupied the second largest share of the mean total household income after income generated from crops.

Consequently, statement F9-Thre is improved security, support and cohesion as a result of building community forest associations. $127(42.8 \%)$ of the respondents agreed, $77(25.9 \%)$ strongly agreed, 38(12.8\%) strongly disagreed, $20(6.7 \%)$ disagreed and $35(11.8 \%)$ of the respondents were neutral. The line item mean score of 3.62 
and SD of 1.288 was higher than the composite mean score of 3.556 and SD of 1.256. This implies that improved security, support and cohesion among CFA members has created a supportive environment which could promote efficient participatory process. This concur with Webler and Tuler (2007) study which indicated majority accepted the fact that good practices require inclusivity and accountability even though there were major gaps in views regarding knowledge access, leadership and control. This underlines the need to recognize the diversity of participants and to determine which mechanisms of collaborative activities require diverse viewpoints to be taken into account.

Table 4. Correlation results between participatory Evaluation and conservation of Mau forest programme

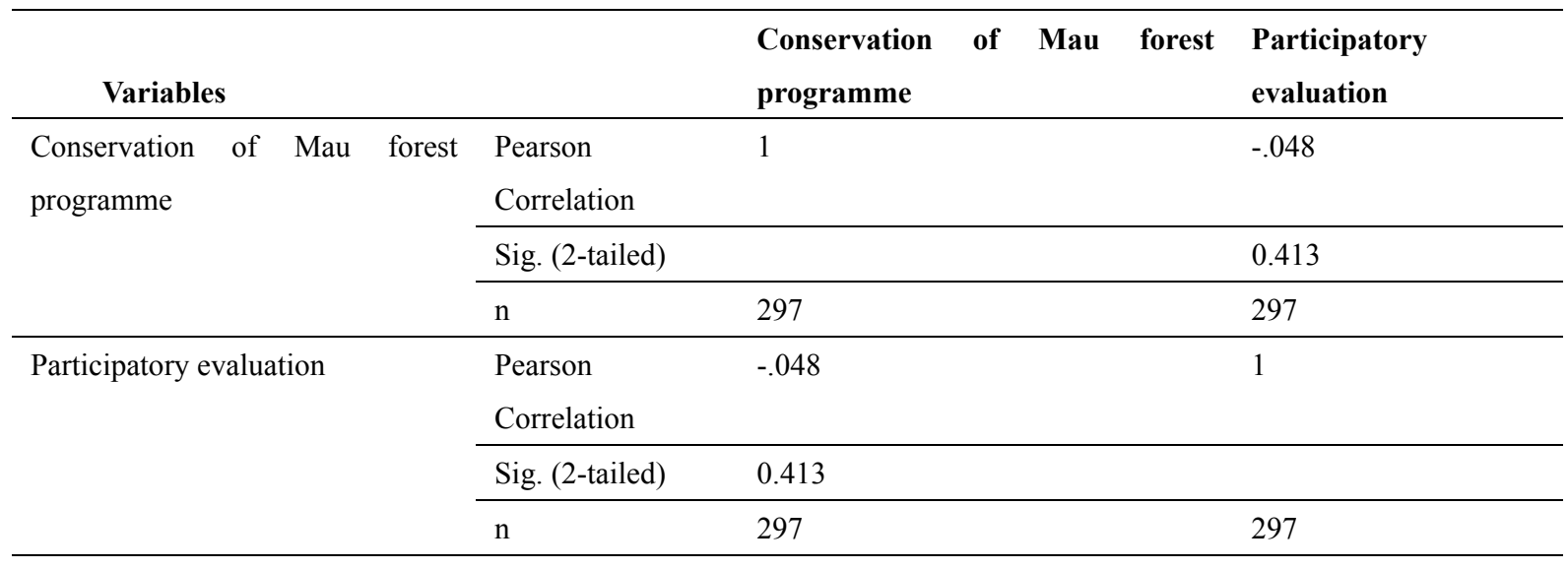

Table 4 shows a correlation index between participatory evaluation and conservation of Mau forest programme. The Pearson's Product Moment Correlation coefficients indicated the value of $r=-0.048$ and a probability of 0.413 . According to Shirley et al. (2005), a strong correlation, " $r$ " ranges from +0.5 and +1.0 ; a moderate correlation, " $r$ " ranges between +0.30 and +0.49 ; and a weak correlation, " $r$ " ranges from +0.10 to +0.29 . The positive or negative sign points to the direction of the relationship. It can therefore be argued that for $\mathrm{r}<0.1$, there was a weak negative linear correlation between the two variables under investigation, since $r=-0.048$. The $p$-value of 0.413 was found to be greater than 0.05 level of significance which implies that this weak relationship was not significant. Furthermore, the findings is supported by qualitative data from KFS officers interviewed who said that:

"The community user-groups obtained a lot of forest products form Mau Forest which has led to improved livelihood of the people. In addition, the products obtained from the forest include fuel-wood, honey, fodder and herbal medicine. Moreover, the roads linkage has been improved in the area and schools surrounding forest area normally receive support from donors. " KFS officer

\subsection{Regression Analysis between Participatory Evaluation and Conservation of Mau Forest Programme}

$\mathrm{R}$ squared was used to show variation in conservation of Mau forest programme which can be explained by Participatory evaluation. The results were shown on Table 5.

Table 5. Model summary for participatory Evaluation and Conservation of Mau forest programme

\begin{tabular}{|c|c|c|c|c|}
\hline Model & $\mathbf{R}$ & R Square & $\begin{array}{c}\text { Adjusted R } \\
\text { Square }\end{array}$ & Std. Error of the Estimate \\
\hline 1 & $0.048^{\mathrm{a}}$ & 0.002 & -.001 & 4.50441 \\
\hline
\end{tabular}

a. Predictors: (Constant), Participatory evaluation

$\mathrm{R}^{2}=0.002$ shows how much participatory evaluation predicts conservation of Mau Forest. Hence, $0.2 \%$ is predicting hence active participation of stakeholders in evaluating their activities would result in improved conservation of Mau Forest. The Standard error is 4.504, which is lower than 5\% indicates that if stakeholders regularly participate in evaluation of their practices on programme implementation, there would be improvement on conservation of Mau Forest programme. 


\subsection{Analysis of Variance between Participatory Evaluation and Conservation of Mau Forest Programme}

Analysis of variance was used to determine whether the model was a good fit for the data in determining the influence of participatory evaluation on Conservation of Mau forest programme. The results are shown on Table 6.

Table 6. ANOVA for participatory evaluation and conservation of Mau forest programme

\begin{tabular}{rlrrrrr}
\hline Model & & \multicolumn{1}{c}{ Sum of Squares } & df & \multicolumn{1}{c}{$\begin{array}{c}\text { Mean } \\
\text { Square }\end{array}$} & F & \multicolumn{1}{c}{ Sig. } \\
\hline 1 & Regression & 13.645 & 1 & 13.645 & .672 & $.413^{\mathrm{b}}$ \\
& Residual & 5985.453 & 295 & 20.290 & & \\
& Total & 5999.098 & 296 & & & \\
\hline
\end{tabular}

b. Predictors: (Constant), Participatory evaluation

Table 6 Shows that the significance level 0.05 was less than the p-value 0.413 . This implies that regression model was not a good fit in predicting the influence of participatory evaluation on conservation of Mau forest programme.

\subsection{Coefficients of Participatory Evaluation and Conservation of Mau Forest Programme}

Table 7 Shows regression coefficients for the influence of Participatory evaluation on conservation of Mau Forest programme.

Table 7. Coefficients for participatory evaluation and conservation of Mau forest programme

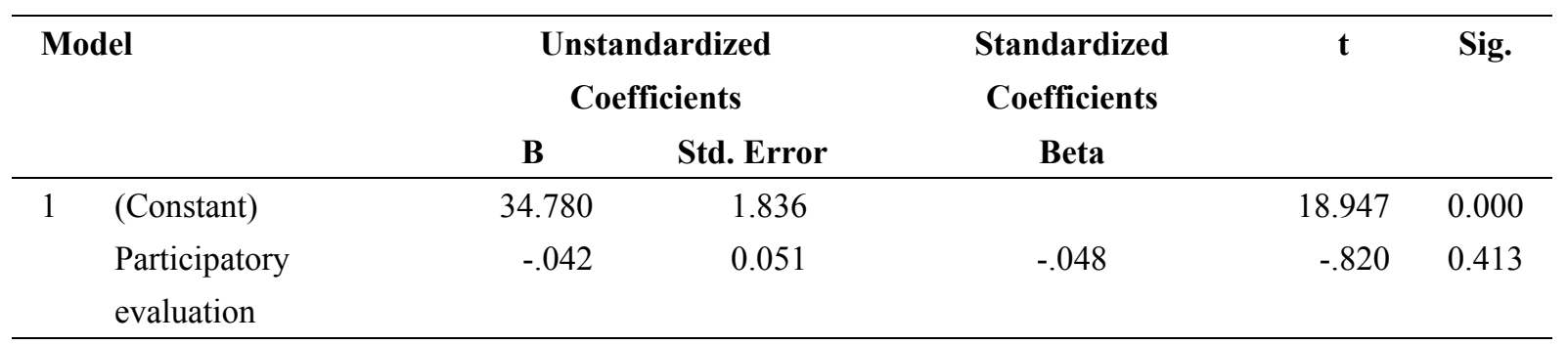

Table 7 shows that participatory evaluation has a negative significant influence on conservation of Mau forest programme as shown by the regression coefficient -0.042 and a p-value 0.413 . The findings indicate that an improvement in conducting participatory evaluation by the Kenya Forest Service and Community Forest Association members leads to effective conservation programmes in Mau Forest.

\subsection{Testing of Hypothesis}

There is no significant relationship between participatory evaluation and conservation of Mau Forest programme. The findings yielded a p-value of 0.413 which is more than 0.05 . Hence, due to limited evidence from the data sampled, null hypothesis failed to be rejected and therefore, concluded that there is no significant relationship between participatory evaluation and conservation of Mau Forest programme.

\section{Conclusions}

This paper made conclusion that Participatory evaluation play a vital role in improving forest conservation programmes in Mau Forest. The study found that stakeholder participation in evaluating forest conservation activities had a positive influence on successful implementation of forest conservation programs. Morever, the findings indicated that the Community Forest Association (CFA) members could not evaluate effectively forest conservation programs due to inadequate technical and financial challenges which hindered effective implementation of Participatory Forest Management programmes.

\section{Recommendations}

It is recommended that trust can be established between state actors and community members if local authorities are strengthened and encouraged to work under the participatory system of forest management. Forest service staff should be equipped with continuous training and knowledge in the modern forest management model. A 
comprehensive and periodic external assessment framework should be implemented so as to ensure proper execution of future projects in true spirit.

\section{References}

Abbas, D. (2007). Harvesting forest biomass for energy in Minnesota: An assessment of guidelines, costs and logistics. Ph.D. dissertation, University of Minnesota, Minnesota, U.S.A.

Agrawal, A., Cashore, B., Hardin, R., Shepherd, G., Benson, C., \& Miller, D. (2013). Economic contributions of forests. United Nations Forum on Forests, Background Paper No.1, Thenth session, 8-19th April, 2013. Instabul, $\quad$ Turkey. $\quad$ Retrieved October 12, 2013, from http://www.un.org/esa/forests/pdf/session_documents/unff10/EcoContrForests.pdf

Allen, M. J., \&Yen, M. W. (2002). Introduction to measurement theory. Long Grove, IL: Waveland press.

Amanor, K. S. (2003). Natural and cultural Assets and participatory Forest management in West Africa. Paper presented at the International Conference on Natural Assets. Philippines.

Anders, S. (2000). Guidelines for participatory forest management planning. FARMAfrica, Addis Ababa

Angelsen, A., \& Rudel, T. K. (2013). Designing and implementing effective REDD+ policies: a forest transition approach Rev. Environ. Econ. Policy, 7, 91-113. https://doi.org/10.1093/reep/res022

Anonymous. (2010). Forestry; University of Saskatchewan reports research in forestry. Journal of Farming, 254.

Anthony, J. O., \& Nancy, L. L. (2004). Linking research questions to mixed methods data analysis procedures. The Qualitative Report Volume 11 Number 3 September 2006 474-498.

Babulo, B., Muys, B., Nega, F., Tollens, E., Nyssen, J., \& Deckers, J. (2009). The economic contribution of forest resource use to rural livelihoods in Tigray, Northern Ethiopia. Forest Policy and Economics, 11(2), 109-117. https://doi.org/10.1016/j.forpol.2008.10.007

Blackstock, K. L., Kelly, G. J., \& Horsey, B. L. (2007). Developing and applying a framework to evaluate $\begin{array}{lllll}\text { participatory research for sustainability. Ecol. Econ., 60, 726-742. } & \end{array}$ https://doi.org/10.1016/j.ecolecon.2006.05.014

Blomley, T., Pfliegner, K., Isango, J., Zahabu, E., Ahrends, A., \& Burgess, N. (2008). Seeing The Wood for the Trees: An Assessment Of The Impact of Participatory Forest Management on Forest Condition In Tanzania. Oryx, 42, 380-391. https://doi.org/10.1017/S0030605308071433

Bowler, D. E., Buyung-Ali, L. M., Healey, J. R., Jones, J. P. G., Knight, T. M., \& Pullin, A. S. (2012). Does community forest management provide global environmental benefits and improve local welfare? Front Ecol Environ, 10(1), 29-36. https://doi.org/10.1890/110040

CBD. (2009). A Good Practice Guide for Sustainable Forest Management. Biodiversity and Livelihoods.

CEE (Collaboration for Environmental Evidence). (2010). Guidelines for Systematic Review in Environmental Management. Collaboration for Environmental Evidence. University of Bangor, Bangor, Wales.

Chakrabartty, S. N. (2011). Measurements of reliability as per definition. In: proceedings of the conference on psychological measurements: Strategies for the new millennium. New Delhi: Indira Gandhi National Open University.

Cohen, R. J., \& Swerdlik, M. E. (2010). Psychological testing and assessment: An introduction to tests and measurement (7th ed.). New York: McGraw-Hill.

Conrad, E., Cassar, L. F., Christie, M., \& Fazey, I. (2011). Hearing but not listening? A participatory assessment of public participation in planning. Environment and Planning C: Government and Policy, 29, 761-782. https://doi.org/10.1068/c10137

Cooper, D., \& Schindler, P. (2007). Business Research Methods. NewYork, McGraw-Hill Higher Education

Cronbach, L. J. (1951). Coefficient alpha and the internal structure of tests. Psychometrika, 16(3), 297-334. https://doi.org/10.1007/BF02310555

DAC (Development Assistance Committee Working Party on Aid Evaluation). (2002). Glossary of Key Terms in Evaluation and Results Based Management. Organisation for Economic Co- operation and Development, Paris.

DeVon, H. A., Block, M. E., Moyle-Wright, P., Ernst, D. M., Hayden, S. J., Lazzara, D., \& Kostas- Polston, E. (2007). A psychometric toolbox for testing validity and reliability. Journal of Nursing Scholarship, 39(2), 
155-164. https://doi.org/10.1111/j.1547-5069.2007.00161.x

Donald, K. K., \& Delno, L. A. (2006). Proposal and Thesis writing. Paulines Publications. Africa.

Ervin, J. (2003). Rapid Assessment and Prioritization of Protected Area Management (RAPPAM) Methodology. WWF, Gland, Switzerland.

FAO. (2010). Global forest resources assessment 2010 Nepal. Country report, Food and Agriculture Organization, Rome.

FARM Africa. (2007). The Key Steps in Establishing Participatory Forest Management: A field manual to guide practitioners in Ethiopia. Ethiopia: SOS Sahel.

Fisher, M. (2004). Household welfare and forest dependence in Southern Malawi. Environment and Development Economics, 9, 135-154. https://doi.org/10.1017/S1355770X03001219

Fisher, R., Prabhu, R., \& McDougall, C. (2007). Introduction: People, forests and the need for adaptation. Adaptive collaborative management of community forests in Asia: Experiences from Nepal, Indonesia and the Philippines. Bogor, Indonesia: Center for International Forestry Research (CIFOR).

Forest Act (2005) - Government of Kenya. (2005). Forests Act 2005. Nairobi, Kenya: The Government Printer.

GAO (Government Accountability Office). (2009). Program Evaluation: A Variety of Rigorous Methods Can Help Identify Effective Interventions. U.S. Government Accountability

Gertler, P. J., Martinez, S., Premand, P., Rawlings, L. B., \& Vermeersch, C. M. J. (2011). Impact Evaluation in Practice. The World Bank, Washington, DC. https://doi.org/10.1596/978-0-8213-8541-8

Ghahramani, S. (2000). Fundamentals of Probability (2nd ed.). Prentice Hall: New Jersey.

Glew, L. (2012). Evaluating the effectiveness of community-based conservation in northern Kenya, Ph.D. Dissertation, Department of Environmental Science. University of Southampton, Southampton, UK.

GOK. (2009). Rehabilitation of the Mau Forest Ecosystem. A Project Concept prepared by the Interim Coordinating Secretariat, Office of the Prime Minister, on behalf of the Government of Kenya Government of Kenya (2014). Ministry of Environment, Water and Natural Resources; Draft National Forest Policy.

Hesslerová, P., \& Pokorný, J. (2010). Effect of Mau Forest Clear Cut on Temperature Distribution and Hydrology of Catchment of Lakes Nakuru and Naivasha: Preliminary Study. In Water and Nutrient Management in Natural and Constructed Wetlands (pp. 263-273). Springer, Netherlands. https://doi.org/10.1007/978-90-4819585-5_19

Huber, P. J. (2004). Robust Statistics. Pub: Wiley.

Kaimowitz, D. (2003). Not by Bread Alone...Forests and Rural Livelihoods in Sub-Saharan Africa. In T. Oskanen, B. Pajari, \& T. Tuomasjukka (Eds.), Forests in Poverty Reduction Strategies: Capturing the Potential, EFI Proceedings No. 47. Joensuu, Finland: European Institute.

Kapoor, I. (2001). Towards participatory environmental management? Journal of Environmental Management, 63, 269-279. https://doi.org/10.1006/jema.2001.0478

Kapos, V. et al. (2008). Calibrating conservation.

Kathleen, L. W., \& Linda, E. K. (2010). Urban Forestry Research Needs: A Participatory Assessment Process. Journal of Forestry. Bethesda: Jan/Feb 2010, 108(1), 39-44.

Kenya National Bureau of Statistics.(2013). Kenya Facts and Figures 2013. http://www.knbs.or.ke/index/kenyafacts2013.pdf. 20/5/2014. and hydrologic properties for River Njoro catchment in Eastern Mau, Kenya. Journal of Science, Technology, Education and Management, 1 (2), 14-27 Report of Kenya Forest Working Group, Nairobi, Kenya, pp.15.

Kohlin, G., \& Parks, P. (2001). Spatial variability and disincentives to harvest: Deforestation and fuelwood collection in South Asia. Land Economics, 77, 206-18. https://doi.org/10.2307/3147090

Kothari, C. R. (2004). Research Methodology: Methods and Techniques (2nd ed.). New Age International (P) Limited, Publishers. New Delhi, India.

Kothari, C. R. (2009). Research methodology: methods and techniques. New Age International. Retrieved from http://books.google.com/books?hl=en\&lr=\&id=8c6gkbKi-

4C\&oi=fnd\&pg=PR7\&dq=research + methodology, + methods

Larry, H. (2013). Advanced Statistics in Research: Reading, Understanding, and Writing Up Data Analysis Results. 
Publisher: Shadow Finch Media LLC.

Le, K. T., Brick, J. M., Diop, A., \& Alemadi, D. (2013). Within-household Sampling Conditioning on Household Size. International Journal of Public Opinion Research, 25, 108-118. https://doi.org/10.1093/ijpor/eds008

Lee, D. K., \& Park, Y. K. (2001). Degradation Issues in Southeast and Northeast Asia. Proceedings of 10th International workshop of BIO-REFOR. The University of Tokyo, Tokyo.

Lescuyer, G. (2010). Economic importance of Non Timber Forest Products in some villages of South Cameroon. Bois et forêts des tropiques, 304(2). https://doi.org/10.19182/bft2010.304.a20442

Leverington, F. et al. (2010).Management Effectiveness of Evaluation in Protected Areas - A Global Study (2nd ed.). University of Queensland, Brisbane, Australia.

Lise, W. (2000). Factors influencing people's participation in forest management in India. Ecological Economics, 34, 379-392. https://doi.org/10.1016/S0921-8009(00)00182-8

Matiku, P., Ogol, C., \& Mireri, C. (2011). The impact of participatory forest management (PFM) on forest integrity and biodiversity in Arabuko-Sokoke forest, Kenya. Afr. J. Ecol. https://doi.org/10.1111/j.13652028.2011.01311.x

Matta, J., Alavalapati, J., Kerr, J., \& Mercer, E. (2005). Agency perspectives on transition to participatory forest management: A case study from Tamil Nadu, India. Society and Natural Resources, 18(10), 859-870. https://doi.org/10.1080/08941920500248749

Mbuvi, M. T. E., Maua, J. O., Ongugo, P. O., Koech, C. K., Othim, R. A., \& Musyoki, J. K. (2009). Status of the Participatory Forest Management impacts on Poverty for Buyangu non-PFM area adjacent community: Kakamega Forest; Kakamega District. Kenya Forestry Research Institute (KEFRI).

McDermott, M. H., \& Schreckenberg, K. (2009). Equity in Community Forestry: Insights from North and South. International Forestry Review, 11(2), 157-170. https://doi.org/10.1505/ifor.11.2.157

Mcfarlane, B. L., \& Boxall, P. C. (2000). Factors influencing forest values and attitudes of two stakeholder groups: The case of the Foothills Model Forest, Alberta, Canada. Society and Natural Resources, 13, 649-661. https://doi.org/10.1080/08941920050121927

Mellenbergh, G. J. (2008). Tests and questionnaires analysis. Advising on research methods: A consultant's companion, 235-268.

MENR. (2005). The Kenya forests act. Ministry of Environment and Natural Resources.

MENR. (2016). The Kenya forest act, 2016. Ministry of Environment and Natural Resources.

Miteva, D. A., Pattanayak, S. K., \& Ferraro, P. J. (2012). Evaluation of biodiversity policyinstruments: what works and what does not? Oxford Review of Economic Policy, 28, 69-92. https://doi.org/10.1093/oxrep/grs009

Mustalahti, I. (2006). How to handle the stick: Positive processes and crucial barriers of Participatory Forest Management. Forests, Trees and Livelihoods, 16(2), 151-165. https://doi.org/10.1080/14728028.2006.9752553

NEMA. (2009). Fourth National Report to the Conference of Parties to the Convention on Biodiversity.

Neumann, R. P. (2005). Making political ecology. London: Hodder Arnold.

NOAA (National Oceanic and Atmospheric Administration). (2010). Marine Protected Area Management Assessment Checklist. U.S. National Oceanic and Atmospheric Administration, Washington, DC.

NOAA (National Oceanic and Atmospheric Administration). (2011). User's Guide for the NOAA Coral Reef Conservation Program MPA Checklist. U.S. National Oceanic and Atmospheric Administration, Washington, DC.

Nunnaly, J. (1978). Psychometric theory. New York: McGraw-Hill.

Ongugo, P. O., Mogoi, J., Obonyo, E., \& Oeba, V. (2008). Examining the roles of community forest associations (cfas) in the decentralization process of Kenyan forests. In Conference Paper Presented at the IASC Conference in England.

Oso, \& Onen. (2009). A general guide to writing research proposal and report. Options press \& Publishers.

Patton, M. Q. (2003). Utilization-focused evaluation. In Kellaghan, T., \& Stufflebeam, D. L. (Eds.), International Handbook of Educational Evaluation: Part One (pp. 223-244). Kluwer Academic Publishers, Norwood, MA. https://doi.org/10.1007/978-94-010-0309-4_15 
Pavese, H. B., Leverington, F., \& Hockings, M. (2007). Global study of protected areas management effectiveness: the Brazilian perspective. Natureza \& Conservacao, 5, 152-162

Phiri, M., Chirwa, P. W., Watt, S., \& Syampungani, S. (2012). Local community perception of joint forest management and its implications for forest condition: the case of Dambwa Forest Reserve in southern Zambia. Southern Forests, 74, 52-59. https://doi.org/10.2989/20702620.2012.686203

Potter, R. B., Binns, T., Elliot, J. A., \& Smith, D. (1999). Geographies of Development. Harlow, Longman.

Pullin, A. S., \& Knight, T. M. (2009). Doing more good than harm - building an evidence base for conservation and environmental management. Biological Conservation, 142, 931-934. https://doi.org/10.1016/j.biocon.2009.01.010

Quan, J., Ouyang, Z. Y., Xu, W. H., \& Miao, H. (2011). Assessment of the effectiveness of nature reserve management in China. Biodiversity and Conservation, 20, 779-792. https://doi.org/10.1007/s10531-0109978-7

Reddy, M. V. (2002). Introduction. In Reddy M.V. (Ed.), Management of Tropical Plantation- Forests and their Soil Litter System. Litter, Biota and Soil-Nutrient Dynamics (pp. 1-40). Science Publisher Inc, USA.

Reed, M. S. (2008). Stakeholder participation for environmental management: a literature review. Biological conservation, 141, 2417-2431. https://doi.org/10.1016/j.biocon.2008.07.014

Rich, R. F. (1998). Program evaluation and environmental policy: the state of the art. In Knaap, G. J., \& Kim, T. J.(Eds.), Environmental Program Evaluation: A Primer (pp. 23-41). University of Illinois Press, Chicago.

Rowe, G., \& Frewer, L. J. (2000). Public participation methods: A framework for evaluation. Science, technology \& human values, 25, 3-29. https://doi.org/10.1177/016224390002500101

Rudel, T. K., Coomes, O. T., Moran, E., Achard, F., Angelsen, A., Xu, J., \& Lambin, E. (2005). Forest transitions: toward a global understanding of land-use change. Global Environ. Change, 15, 23-31. https://doi.org/10.1016/j.gloenvcha.2004.11.001

Sekaran, U. (2003). Research Methods for Business - A Skill Building Approach (4th ed.). Wiley Publishers.

Shirley, D., Stanley, W., \& Daniel, C. (2005). Statistics for Research (3rd ed.). Publisher: John Wiley \& Sons, Inc.

Singpurwalla, D. (2013). A handbook of Statistics: An overview of statistics. New York: Free Press.

Stem, C., Margoluis, R., Salafsky, N., \& Brown, M. (2005). Monitoring and evaluation in conservation: a review of trends and approaches. Conservation Biology, 19, 295-309. https://doi.org/10.1111/j.15231739.2005.00594.x

Thenya, T., Wandago, B., \& Nahama, E. T. (2007). Participatory forest management experience in Kenya (19962006). In Proceedings of the 1st National Participatory Forest Management Conference. KEFRI Headquarters, Nairobi, Kenya.

Twyman, C., Dougill, A. J., Sporton, D., \& Thomas, D. (2001). Community Fencing in Open Rangelands: A Case Study of Community Self- Empowerment in Eastern Namibia. Review of African Political Economy, 28, 926. https://doi.org/10.1080/03056240108704500

UNDP. (2009). Supporting Capacity Development: The UNDP Approach.

UNDP/GEF. (2005). Measuring and demonstrating impact, In: UNDP/GEF Resource Kit (No. 2). United Nations Environment Department/Global Environment Facility, Washington, DC.

UNEP. (2002). Global Environmental Outlook 3: Past, Present and Future Perspective. London: Sterling V.A. Earth Scan Publication Ltd.

UNEP. (2008). Cdm/ji pipeline analysis and database, march 1st 2008. RISCOE, Roskilde Denmark.

USAID (U.S. Agency for International Development). (2011). USAID Evaluation Policy. U.S. Agency for International Development, Washington, DC.

Vedeld, P., Angelsen, A., Bojo, J., Sjaastad, E., \& Berg, G. K. (2007). Forest environmental incomes and the rural poor. Forest Policy and Economics, 9(7), 869-879. https://doi.org/10.1016/j.forpol.2006.05.008

Webler, T., \& Tuler, S. (2007). Four perspectives on public participation process in environmental assessment and decision making: Combined results from 10 case studies. Policy Studies Journal, 34, 699-722. https://doi.org/10.1111/j.1541-0072.2006.00198.x

Weisberg, H. F. (1992). Central Tendency and Variability. Sage University Paper Series on Quantitaive 
Applications in the Social Sciences. https://doi.org/10.4135/9781412983617

Wholey, J. S. (1997). Trends in performance measurement: challenges for evaluators. In Chelimsky, E., \& Shadish, W. R. (Eds.), Evaluation for the 21 st Century: A Handbook (pp. 124-133). SAGE Publications Inc., Thousand Oaks, California. https://doi.org/10.4135/9781483348896.n8

Wily, L. A. (2002). Participatory Forestry in Africa: An Overview of Progress and Issues. In Second International Workshop On Participatory Forestry in Africa: Defining The Way Forward: Sustainable Livelihoods and Sustainable Forest Management Through Participatory Forestry. Proceedings of the Second International Workshop on Participatory Forestry in Africa.

World Bank. (2006). Agricultural Investment Sourcebook. Module 12 "Scaling Up Agricultural Investments in the Bank's Changing Internal Environment." Washington, D.C.

Yamane, T. (1967). Statistics: An Introductory Analysis (2nd ed.). New York: Harper and Row.

\section{Copyrights}

Copyright for this article is retained by the author(s), with first publication rights granted to the journal.

This is an open-access article distributed under the terms and conditions of the Creative Commons Attribution license (http://creativecommons.org/licenses/by/4.0/). 